\title{
Olefin Cyclopropanations via Sequential Atom Transfer Radical Addition-Dechlorination Reactions
}

\author{
Katrin Thommes $\S^{\star}$ and Kay Severin \\ §SCS-DSM Nutritional Products Award Winner (Poster Presentation)
}

\begin{abstract}
In organic synthesis, cyclopropanation reactions are often performed with Simmons-Smith-type reagents or by transition metal catalyzed reactions of olefins with diazo compounds. A novel method for the synthesis of substituted cyclopropanes is described that is based on a two-step reaction sequence. Olefins are reacted with 1,1'-dichlorides in a Ru-catalyzed atom transfer radical addition (ATRA) process and the resulting 1,3-dichlorides are directly converted into cyclopropanes by reductive coupling with magnesium. This one-pot procedure is applicable to a variety of substrates and can be performed in an inter- or intramolecular fashion.
\end{abstract}

Keywords: Carbocycles · Cyclopropanes · Magnesium $\cdot$ Radicals $\cdot$ Ruthenium

\section{Introduction}

In the 1940s, Kharasch and co-workers discovered that halocarbons, such as $\mathrm{CCl}_{4}$, could be added to olefins through a radical chain process. ${ }^{[1]}$ Three decades later, the scope of the reaction was expanded by the discovery that the ruthenium complex $\left[\mathrm{RuCl}_{2}\left(\mathrm{PPh}_{3}\right)_{3}\right]$ is able to act as an efficient catalyst for this reaction. ${ }^{[2]}$ Over the past years, several catalysts with improved catalytic performances have been developed and meanwhile many transition metal complexes are known to promote inter- and intramolecular ATRA reactions. ${ }^{[3]}$ The highest activities are typically found for copper ${ }^{[4]}$ and ruthenium ${ }^{[5]}$ catalysts and interesting applications have been reported in organic synthesis. ${ }^{[6]}$ Despite their high activities, a main disadvantage from a practical point of view remained the catalyst stability; hence high catalyst loadings

${ }^{*}$ Correspondence: K. Thommes

Institut des Sciences et Ingénierie Chimiques

École Polytechnique Fédérale de Lausanne (EPFL)

$\mathrm{CH}-1015$ Lausanne

Tel.: +41216939313

Fax: +41216939305

E-mail: katrin.thommes@epfl.ch were needed. Recently it was reported that the lifetime of the catalyst could be drastically improved by using a co-catalyst, which acts as a reducing agent to regenerate the active species. ${ }^{[7]}$ One of the best systems described so far is the air-stable half-sandwich complex $\left[\mathrm{RuCl}_{2} \mathrm{Cp}^{*}\left(\mathrm{PPh}_{3}\right)\right]$ (1) that is employed in conjunction with $\mathrm{AIBN}^{[7 \mathrm{~d}]}$ or $\mathrm{Mg}^{[7 \mathrm{~b}]}$ as the co-catalyst. The role of the co-catalyst is the activation of the $\mathrm{Ru}^{\mathrm{III}}$ catalyst by reduction to $\mathrm{a} \mathrm{Ru}^{\mathrm{II}}$ complex, and the prevention of an accumulation of $\mathrm{Ru}^{\mathrm{III}}$ complexes due to termination reactions of carbon-centered radicals. ${ }^{[8]}$ This method allows intermolecular ATRA reactions and intramolecular atom transfer radical cyclization (ATRC) reactions to be performed with high efficiency. The addition products are 1,3-dihalides. It had been reported that in the presence of various metals, such as $\mathrm{Na},{ }^{[9]} \mathrm{Mg},{ }^{[10]}$ $\mathrm{Zn},{ }^{[11]}$ Grignard compounds, ${ }^{[12]}$ or transition metal complexes, ${ }^{[13]}$ cyclopropanes can be obtained by reductive coupling of 1,3-dihalogen derivatives. We were thus interested to explore the possibility to combine Ru-catalyzed ATRA and ATRC reactions with a dehalogenation step to produce cyclopropanes. Our preliminary results, which were recently published, ${ }^{[14]}$ are summarized below.

\section{Sequential ATRA/ATRC- Dechlorination Reactions}

The catalytic system based on a combination of magnesium and the ruthenium catalyst $\mathbf{1}$, which is air-stable and can be easily synthesized from $\left[\mathrm{Cp}^{*} \mathrm{RuCl}\right]_{2}$ and
$\mathrm{PPh}_{3}{ }^{[15]}$ is well suited for difficult atom transfer radical reactions. The addition of dichlorinated substrates to olefins or intramolecular ATRC reactions are performed with very good yields. The addition products, 1,3-dichlorides, were promising candidates for a sequential dichlorination step.

Screening of different reactions conditions revealed that $\mathrm{Mg}$ in combination with THF can induce a cyclization of the ATRA product of styrene and ethyl dichloroacetate. As it was found that the radical addition was best performed in a non-polar organic solvent such as toluene, a one-pot, two-step reaction was employed (Scheme 1). The ATRA reaction was first performed in toluene and the mixture was then diluted with THF. This procedure gave 2-phenylcyclopropane-1-carboxylic acid ethyl ester in good yields.

A similar procedure was successfully used for numerous chlorinated substrates and olefins. Styrene derivatives were reacted with ethyl dichloroacetate, dichloroacetonitrile, and chloroform to give the corresponding cyclopropanes as a mixture of cis-trans isomers (Scheme 2). Cyclopropanecarboxamides can also be obtained by this method as shown by the reaction of styrene with a dichloroacetamide. More difficult substrates like methylmethacrylate, which shows a high tendency to form polymeric side products, and the internal olefin cyclohexenylbenzene could be coupled to ethyl dichloroacetate to give the corresponding cyclopropanes in acceptable yields (Scheme 2).

From the synthetic point of view, intramolecular atom transfer reactions are very 


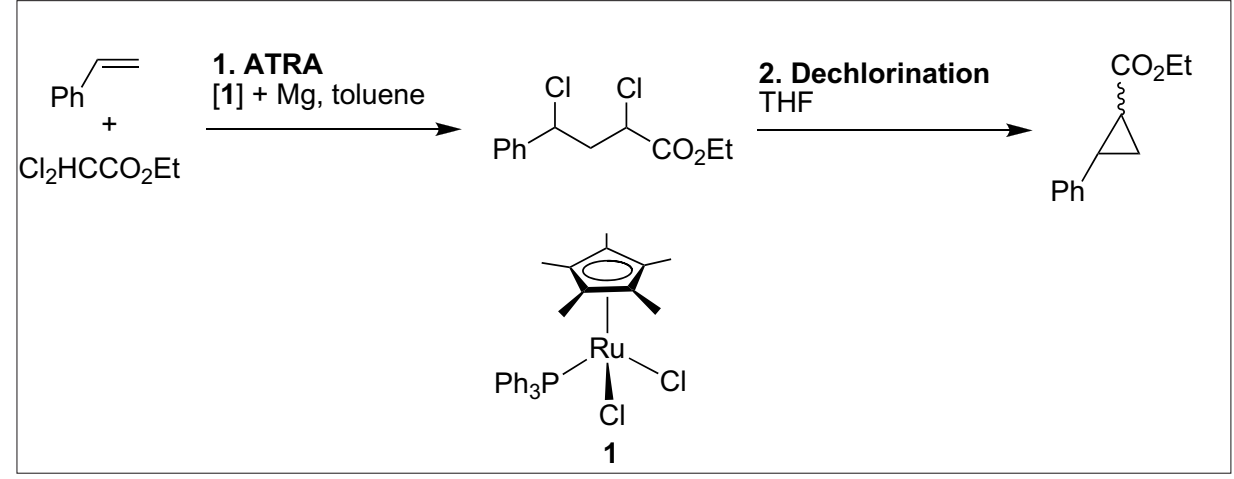

Scheme 1. One-pot sequential ATRA-dechlorination reaction of styrene and ethyl dichloroacetate.

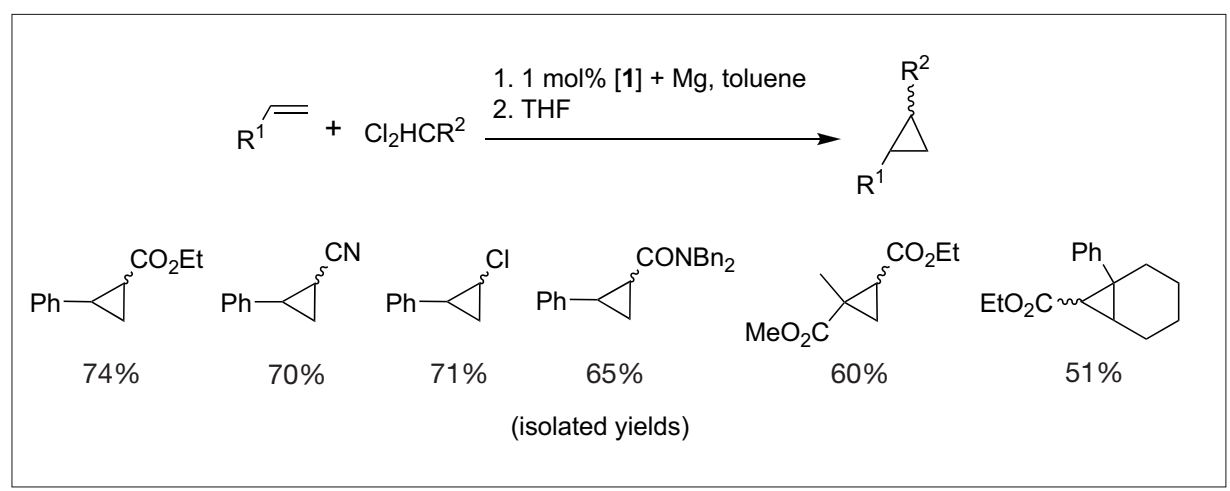

Scheme 2. Selected products for ATRA-dechlorination reactions catalyzed by complex 1 in the presence of Mg.

interesting. The synthetic method outlined above also allows the synthesis of bicyclic systems in a one-pot reaction. Two different classes of substrates, trichlorinated allylethers and di- and trichlorinated $\mathrm{N}$ allylacetamides, were employed and the corresponding cyclopropanes could be isolated in respectable yields.

3-Oxabicyclo[3.1.0]hexanes were obtained by cyclization of [(2,2,2-trichloroethoxy)prop-1-enyl]benzene or (3-(2,2,2-trichloroethoxy)prop-1-en-2-yl)benzene (Scheme 3). Although different synthetic routes have been suggested for this structural motif,[16] the method is interesting because the starting materials are easily accessible and because the chloro substituent in the product can be used for further functionalisation.

Different $\quad N$-allyl-2,2-dichloroacetamides were successfully cyclized to give the corresponding 3-azabicyclo[3.1.0] hexan-2-one derivatives (Scheme 4). This bicyclic lactam-cyclopropane framework has been of interest, because 3-azabicyclo[3.1.0] hexan-2-one is a precursor of cis- 2-aminomethylcyclopropanecarboxylic acid (CAMP). ${ }^{[17]}$

In most cases the dechlorination step was very fast. This was surprising since 1,3-dichlorides are significantly less reactive than 1,3-diiodides or 1,3-dibromides. If the reaction was performed with the isolated ATRA product of chloroform and styrene as a model compound, the $\mathrm{Ru}$ complex was found to accelerate the dechlorination reaction substantially, and an induction period was observed. More detailed mechanistic studies are currently being pursued in our laboratory.

\section{Conclusion}

A novel method for the synthesis of substituted cyclopropanes has been described. Olefins are reacted with 1,1'-dichlorides in a $\mathrm{Ru}$-catalyzed atom transfer radical addition process and the resulting 1,3-dichlorides are directly converted into cyclopropanes by reductive coupling with magnesium. This one-pot reaction is applicable to a variety of substrates and can be performed in an inter- or intramolecular fashion. The cyclopropanation of ATRC products provides a convenient method to build up bicyclic systems. The method has the advantage that the starting materials are readily accessible and that the utilization of potentially problematic diazo compounds is avoided. Furthermore, the $\mathrm{Ru}$-catalyst is air-stable, easy to synthesize and the co-catalyst magnesium is cheap and non-toxic.

\section{Acknowledgments}

This work was supported by the Swiss National Science Foundation and by the EPFL. We thank Gregor Kiefer for his help with the substrate synthesis and Rosario Scopelliti for the crystallographic analysis.

Received: January 15, 2010

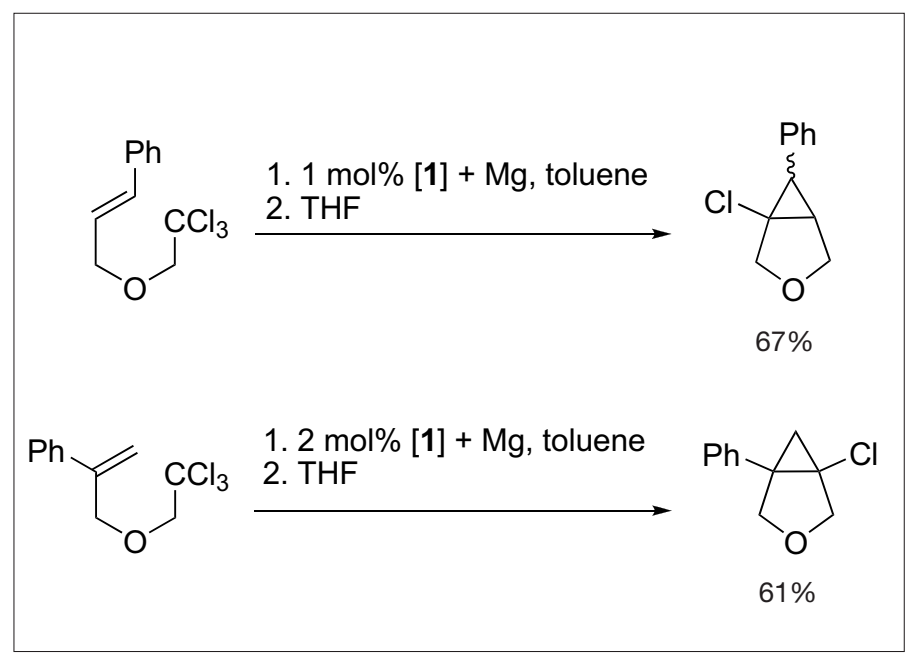

Scheme 3. Sequential ATRC-dechlorination reactions of trichlorinated allylethers.

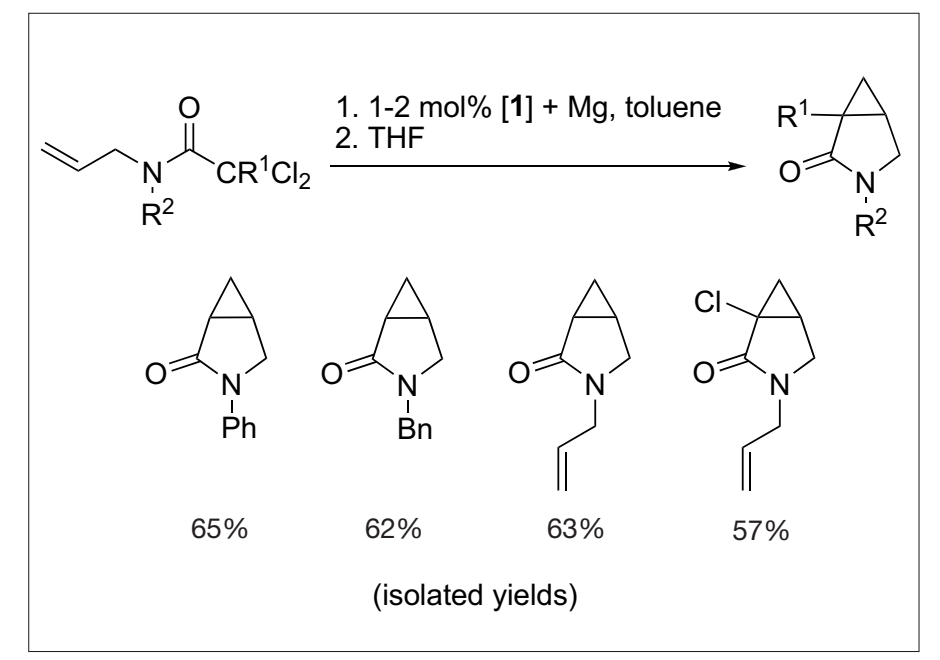

Scheme 4. Sequential ATRC-dechlorination reactions of di- and trichlorinated $N$-allylacetamides. 
[1] M. S. Kharasch, E. V. Jensen, W. H. Urry, Science 1945, 102, 128.

[2] H. Matsumoto, T. Nakano, Y. Nagai, Tetrahedron Let. 1973, 51, 5147.

[3] For reviews see: a) K. Severin, Curr. Org. Chem. 2006, 10, 217; b) L. Delaude, A. Demonceau, A. F. Noels in 'Topics in Organometallic Chemistry', Vol. 11, Eds. C. Bruneau, P. H. Dixneuf, Springer, Berlin, 2004, p. 155.

[4] Selected examples: a) C. Ricardo, T. Pintauer, Chem. Commun. 2009, 3029; b) T. Pintauer, W. T. Eckenhoff, C. Ricardo, M. N. C. Balili, A B. Biernesser, S. J. Noonan, M. J. W. Taylor, Chem. Eur. J. 2009, 15, 38; c) J. M. MuñozMolina, T. R. Belderraín, P. J. Pérez, Adv. Synth. Catal. 2008, 350, 2365; d) J. A. Bull, M. G. Hutchings, C. Luján, P. Quayle, Tetrahedron Lett. 2008, 49, 1352; e) R. N. Ram, N. Kumar, Tetrahedron Lett. 2008, 49, 799; f) J. A. Bull, M. G. Hutchings, P. Quayle, Angew. Chem. 2007, 119, 1901; Angew. Chem., Int. Ed. 2007, 46, 1869; g) J. M. Muñoz-Molina, A. Caballero, M. M. Díaz-Requejo, S. Trofimenko, T. R. Belderraín, P. J. Pérez, Inorg. Chem. 2007, 46, 6858; h) C. V. Stevens, E. Van Meenen, K. G. R. Masschelein, Y. Eeckhout, W. Hooghe, B. D'hondt, V. N. Nemykin, V. V. Zhdankin, Tetrahedron Lett. 2007, 48, 7108; i) D. Yang, Y.-L. Yan, B.-F. Zheng, Q. Gao, N.-Y. Zhu, Org. Lett. 2006, 8, 5757.

[5] Selected examples: a) J. Wolf, K. Thommes, O. Briel, R. Scopelliti, K. Severin, Organometallics 2008, 27, 4464; b) R. J. Lundgren, M. A. Rankin, R. McDonald, M. Stradiotto, Organometallics 2008, 27, 254; c) B. Dutta, E. Solari, R. Scopelliti, K. Severin, Organometallics 2008, 27, 423; d) Y. Borguet, A. Richel, S. Delfosse, A. Leclerc, L. Delaude, A. Demonceau, Tetrahedron Lett. 2007, 48, 6334; e) Y. Motoyama, S. Hanada, K. Shimamoto, H. Nagashima, Tetrahedron 2006, 62, 2779; f) L. Quebatte, E. Solari, R. Scopelliti, K. Severin, Organometallics 2005, 24, 1404; g) Y. Motoyama, S. Hanada, S. Niibayashi, K. Shimamoto, N. Takaoka, H. Nagashima, Tetrahedron 2005, 61, 10216; h) L. Quebatte, M. Haas, E. Solari, R. Scopelliti, Q. T. Nguyen, K. Severin, Angew. Chem., Int. Ed. 2005, 44, 1084; i) L. Quebatte, R. Scopelliti, K. Severin, Eur. J. Inorg. Chem. 2005, 3353; j) L. Quebatte, R. Scopelliti, K. Severin, Angew. Chem., Int. Ed. 2004, 43, 1520; k) B. T. Lee, T. O. Schrader, B. Martín-Matute, C. R. Kauffman, P. Zhang, M. L. Snapper, Tetrahedron 2004, 60, 7391; 1) O. Tutusaus, S. Delfosse, A. Demonceau, A. F. Noels, C. Viñas, F. Teixidor, Tetrahedron Lett. 2003, 44, 8421; m) O. Tutusaus, C. Viñas, R. Núñez, F. Teixidor, A. Demonceau, S. Delfosse, A. F. Noels, I. Mata, E. Molins, J. Am. Chem. Soc. 2003, 125, 11830; n) B. de Clercq, F. Verpoort, Tetrahedron Lett. 2002, 43, 4687; o) F. Simal, L. Wlodarczak, A. Demonceau, A. F. Noels, Eur. J. Org. Chem. 2001, 14, 2689; p) F. Simal, L. Wlodarczak, A. Demonceau, A. F. Noels, Tetrahedron Lett. 2000, 41, 6071.

[6] For reviews see: a) T. Pintauer, K. Matyjaszewski, Chem. Soc. Rev. 2008, 37, 1087 ; b) H. Nagashima in 'Ruthenium in Organic Synthesis', Ed. S.-I. Murahashi, WILEY-VCH, Weinheim, 2004, p. 333; c) A. J. Clark, Chem.
Soc. Rev. 2002, 31, 1; d) K. I. Kobrakov, A. V. Ivanov, J. Heterocyclic Chem. 2001, 37, 529; e) R. A. Gossage, L. A. van de Kuil, G. van Koten, Acc. Chem. Res. 1998, 31, 423; f) J. Iqbal, B. Bhatia, N. K. Nayyar, Chem. Rev. 1994, 94, 519; i) F. Minisci, Acc. Chem. Res. 1975, 8, 165.

[7] a) W. T. Eckenhoff, S. T. Garrity, T. Pintauer, Eur. J. Inorg. Chem. 2008, 563; b) K. Thommes, B. Içli, R. Scopelliti, K. Severin, Chem. Eur. J. 2007, 13, 6899; c) W. T. Eckenhoff T. Pintauer, Inorg. Chem. 2007, 46, 5844; d) L. Quebatte, K. Thommes, K. Severin, J. Am. Chem. Soc. 2006, 128,7440

[8] M. A. Fernández-Zúmel, K. Thommes, G. Kiefer, A. Sienkiewicz, K. Pierzchala, K. Severin, Chem. Eur. J. 2009, 15, 11601.

[9] a) M. S. Newman, J. R. LeBlanc, H. A. Karnes, G. Axelrad, J. Am. Chem. Soc. 1964, 86, 868; b) K. B. Wiberg, G. M. Lampman, Tetrahedron Lett. 1963, 30, 2173; c) A. Freund, J. Prakt. Chem. 1982, 26, 367.

[10] a) J. T. Gragson, K. W. Greenlee, J. M. Derfer, C. E. Boord, J. Am. Chem. Soc. 1953, 75, 3344 ; b) E. L. McCaffery, S. W. Shalaby, J. Organomet. Chem. 1972, 44, 227.

[11] a) D. Sakuma, H. Togo, Tetrahedron 2005, 61, 10138; b) A. A. Kamyshova, E. T. Chukovskaya, R. K. Freidlina, Izvest. Akad. Nauk SSSR 1979, 7, 161; c) R. G. Kelso, K. W. Greelees, J. M. Derfer, C. E. Boord, J. Am. Chem. Soc 1955, 77, 1751, d) R. G. Kelso, K. W. Greelees, J. M. Derfer, C. E. Boord, J. Am Chem. Soc. 1952, 74, 297; e) R. W. Shortridge, R. A. Craig, K. W. Greenlees, J. M. Derfer, C. E. Boord, J. Am. Chem. Soc. 1948, 70, 946; f) G. Gustavson, J. Prakt. Chem. 1887, 36, 300.

[12] a) C. H. DePuy, G. M. Dappen, K. L. Eilers, R. A. Klein, J. Org. Chem. 1964, 29, 2813; b) M. S. Kharasch, M. Weiner, W. Nudenberg, A. Bhattacharya, T.-I. Wang, N. C. Yang, J. Am. Chem. Soc. 1961, 83, 3232.

[13] a) T. Takeda, K. Shimane, T. Fujiwara, A. Tsubouchi, Chem. Lett. 2002, 290; b) S. Takahashi, Y. Suzuki, N. Hagiara, Chem. Lett. 1974, 1363; c) P. B. Chock, J. Halpern, J. Am. Chem. Soc 1969, 91, 582; d) J. K. Kochi, D. M. Singleton, J. Org. Chem. 1968, 33, 1027.

[14] K. Thommes, G. Kiefer, R. Scopelliti, K. Severin, Angew, Chem., Int. Ed. 2009, 48, 8115.

[15] T. Arliguie, C. Border, B. Chaudret, J. Devillers, R. Poilblanc, Organometallics 1989, 8, 1308.

[16] a) G.-Q. Tian, M. Shi, Org. Lett. 2007, 9, 4917; b) M. S. Baird, V. M. Boitsov, A. V. Stepakov, A. P. Molchanov, J. Kopf, M. Rajaratnam, R. R. Kostikov, Tetrahedron 2007, 63, 7717; c) M. Lautens, P. H. M. Delanghe, J. Am. Chem. Soc. 1994, 116, 8526; d) H. Maskill, J. Chem. Soc., Perkin Trans. 2 1995, 197; e) M. S. Baird, J. Chem. Soc., Chem. Commun. 1971, 1145.

[17] a) D. L. Crittenden, A. Park, J. Qiu, R. B. Silverman, R. K. Duke, G. A. R. Johnston, M. J. T. Jordan, M. Chebib, Bioorg. Med. Chem. 2006, 14, 447; b) J. E. Carland, A. J. Moorhouse, P. H. Barry, G. A. R. Johnston, M. Chebib, J. Biol. Chem. 2004, 279, 54153; c) R. K. Duke, M. Chebib, V. J. Balcar, R. D. Allan, K. N. Mewett, G. A. R. Johnston, J. Neurochem. 2000, 75, 2602; d) R. D. Allan, D. R. Curtis, P. M. Headley, G. A. R. Jonston, D. Lodge, B. Twitchin, J. Neurochem. 1080, 34, 652. 